\title{
Adherence to International Anatomical Terminology by a Government-implemented High School Biology Science Education Curriculum
}

\author{
Uso de la Terminología Anatómica Internacional en el \\ Currículo Nacional de Biología en Enseñanza Media
}

Gabriel Caro $^{1,2}$; Ignacio Roa ${ }^{3,4,5}$; Alonso Hormazábal-Peralta ${ }^{1}$ \& Pablo A. Lizana ${ }^{1}$

CARO, G.; ROA, I.; HORMAZABAL-PERALTA, A.; LIZANA, P. A. Adherence to international anatomical terminology by a government-implemented high school biology science education curriculum. Int. J. Morphol., 36(3):785-791, 2018.

SUMMARY: Chilean science education curriculum is standardized and issued by the Ministry of Education (MINEDUC). This study contributes to science education analyzing a government implemented high school biology curriculum and its adherence to the Federative International Programme for Anatomical Terminology (FIPAT). The purpose of this study was to assess the use of International anatomical terminology (IAT) in Chilean national biology education programs. The sample consisted of biology programs for 9 th to 12 th grades obtained from the MINEDUC website, in force since 2009. An analysis of terms used in MINEDUC high school programs (9th to 12th grade) was carried out. Terms were identified using Atlas ti text analysis software. Subsequently, the identified terms were tabulated as follows: frequency, Latin term, Spanish translation, use of the term according to FIPAT and type of error. Our results showed that $11.43 \%$ of the terminology used in the high school biology curriculum did not adhere to the IAT in FIPAT. 11 th grade's biology education curriculum showed the highest use of FIPAT terminology and also the same grade showed the highest prevalence of misused terms. These results can serve as an important basic resource for the revision and standardization of terminology used in biomedical fields. Collaboration between anatomists, biologists and high school teachers is a requirement necessary to make changes in the curricula in order to improve the use of IAT in teacher training and in Biology and Natural sciences classes.

KEY WORDS: Anatomical techniques; Science education; High school students; Biology teaching

\section{INTRODUCTION}

A sustained approach to communication skills training will help to equip our students to communicate easily with many aspects of modern society (Evans, 2013). In any discipline, the use of clear and specific language is essential for the exchange of knowledge and the reproduction of findings and results generated (Gómez et al., 2012). Particularly in morphology topics, terminology has evolved over time, making it the subject of considerable controversy and disagreement, hindering scientific communication (Whitmore, 1999; Kachlik et al., 2008; Martin et al., 2009; Burdan et al., 2016; Strzelec et al., 2017). Therefore, several attempts have been made on multiple occasions to unify the terminology in a universal language (Algieri et al., 2013). The use of International Anatomical Terminology (IAT) emerges as the most contemporary aim for the unification of associated vocabulary in morphological sciences (Algieri et al.; Burdan et al.; Strzelec et al.).

Interest in unifying anatomical, embryological and histological terms is explained as if it is only one code, highly defined and with a descriptive character exists; it could lead to an easier learning-teaching process in the mentioned area. In addition to, it helps to avoid misunderstandings in scientific communication in the same geographical zone and also in other places of the world (Algieri et al.).

\section{Linguistic variations in morphology.}

The use of language in applied morphological sciences causes terminological variations that transgress the

${ }^{1}$ Laboratory of Morphological Sciences, Instituto de biología, Pontificia Universidad Católica de Valparaíso, Valparaíso, Chile.

${ }^{2}$ Programa de Magister en Didáctica de las Ciencias Experimentales, Pontificia Universidad Católica de Valparaíso, Valparaíso, Chile.

${ }^{3}$ Unidad de Morfología, Departamento de Ciencias Básicas Biomédicas, Facultad de Ciencias de la Salud, Universidad de Talca, Chile.

${ }^{4}$ Programa de Doctorado en Ciencias Morfológicas, Facultad de Medicina, Universidad de La Frontera, Temuco, Chile.

${ }^{5}$ Becario CONICYT-PCHA/Doctorado Nacional/2015-21150235. 
principle of univocity of scientific language (Araujo, 2015). Univocity means that for each concept there is a linked term constituting a lexical-semantic linguistic mechanism in which the technicalities used have a monosemic value. Within anatomical language variations, emphasis is first placed on eponymy, which includes terms referring to names of persons or places which are used to designate names of concrete units such as cities or diseases and specifically in the area of anatomy, the names of structures (Algieri et al.; Araujo; Burdan et al.). Synonymy is another type of variation that occurs when several terms point at the same concept (Algieri et al.; Díaz Rojo, 2001; Jiménez Gutiérrez, 2009; Salgado \& Trujillo, 2010) and is understood to be strongly associated with eponymy, given that different names are often used to identify the same structure (Araujo). A third variation is known as polysemy, where a plurality of meanings exists linked to a word or term (Araujo). Finally, homonymy is the phonic and graphic similarity between two terms which have different meanings (Araujo). There is another kind of variation in terminology, which occurs when in some countries or translations of anatomical writings, assign different names to structures or elements during the transcription process, which generates that a term is named in different ways according to different places (Algieri et al.).

The above mentioned variations are typical of the scientific language and are highly present in morphology, generating controversies and disagreements among specialists in this area (Algieri et al.; Araujo; Díaz Rojo; Jimenez; Salgado \& Trujillo; Acuña et al., 2007). Even more, this miscommunication and ambiguity can cause problems during the process of diagnosis and treatments, and also, in the teaching -learning process of anatomy (Strzelec et al.). But in the case of eponyms its origin is not recent, its apogee was in the XVI and XVII centuries during the scientific revolution, but its oldest records are placed before Christ (Algieri et al.; Cruz et al., 2010; Araujo; Burdan et al.).

\section{Unification and use of international terminology in morphology.}

To avoid variations in terminology associated with morphology, in 1895 , efforts began to unify the language with the development of the Nomina Anatomica of Basel, with Latin as the official language, using simple and brief characters to form structured terms which suppress eponyms (Algieri et al.; Díaz Rojo; Jiménez Gutiérrez; Salgado \& Trujillo; Araujo). Years later, these lists were updated, until in 1989 the creation of the Federative International Committee of Anatomical Terminology (FICAT) would mark an important moment for achieving universalization of the anatomical language. In 1998 members of FICAT published a listing which they called IAT. This was a list of Latin terms and their English translation, and was made up of 7583 anatomical terms (Algieri et al.).

Despite the efforts made in past years for the unification of anatomical terminology, it is necessary to achieve an actual universalization of terms based on the correct use by specialists and professionals linked to anatomy who are responsible for stimulating its knowledge (Algieri et al.). This context highlights the role of the Ibero-Latin American Symposiums of Terminology (SILAT), created by the Pan American Association of Anatomy in 2009. Its purpose is to unify denominations of structures in the region, as to achieve a common scientific language, facilitating learning and communication among professionals. This is achieved through the study, analysis, translation, dissemination and promotion of International Anatomical Terminology from the International Federation of Anatomist Associations (IFAA) (Losardo et al., 2015). This work by SILAT places a new objective on the horizon which is to transcend International Terminology into university teaching programs and health and science institutions around the world to stimulate the application and correct use of this terminology (Losardo et al., 2010, 2015). This can be achieved through a joint effort between SILAT, scientific societies, universities and ministries of education and health in each country to ensure that these results have an impact in the field of research, teaching and medical practice.

\section{Use of international terminology in schools and vocational training processes.}

In Chile, Ministry of Education (MINEDUC) considers that the use of correct terminology in science is important. This is shown in its " 2016 preliminary orientation for preparation of school textbooks for natural sciences education" under the item of Content Management, which notes that both the study text and the didactic teaching guide "should define and rigorously use concepts, principles, laws and terms accepted by the scientific community, which must be up-to-date and validated, and correspond to University levels" (MINSAL, 2015). These considerations are present in basic aspects of form and content of textbooks participating in the bidding process, but performance level and other aspects are unknown. In addition, no studies are reported that account for the current situation in terms of describing correct terminology use associated with anatomy in basic programs and/or educational resources given by the ministry of education (textbooks, standardized tests, guides, among other school support elements). 


\section{MATERIAL AND METHOD}

In the first stage, curricular programs for 9th to 12 th grades were obtained from the MINEDUC website, in force since 2009 (Ministry of Education of Chile, 2017). An analysis of terms used in MINEDUC high school programs (9th to 12th grade) was carried out. Terms were identified using Atlas.ti text analysis software (V8 Windows Scientific Software Development Gmbh, Berlin, Germany). Subsequently, the identified terms were tabulated as follows: frequency, Latin term, Spanish translation, use of the term according to Federative International Programme for Anatomical Terminology (FIPAT) (Federative International Programme for Anatomical Terminology, 2017) and type of error (Table I).

Table I. Identification of terms used in study programs from $9^{\text {th }}$ to $12^{\text {th }}$ grade (MINEDUC). Example of some terms used in 10 th grade program (Unit 2).

\begin{tabular}{|c|c|c|c|c|c|c|}
\hline \multicolumn{3}{|c|}{$\begin{array}{l}\text { Unit 2: Structure and function of living beings: Hormones } \\
\text { and human reproduction/ } 10^{\text {th }} \text { grade study program }\end{array}$} & \multicolumn{2}{|c|}{ International terminology (FIPAT) } & \multirow[b]{2}{*}{ Use of the term } & \multirow[b]{2}{*}{ Error type } \\
\hline Term & Frequency & Term classification & Latin terms & $\begin{array}{l}\text { Spanish } \\
\text { translation }\end{array}$ & & \\
\hline Hormone & 19 & E3.0.0.5.0.0.47 & Hormonum & Hormona & Correct & - \\
\hline Blood & 7 & A12.0.00.009 & Haema; sanguis & Sangre & Correct & - \\
\hline Ovary & 6 & H3.07.01.1.00001 & Ovarium & Ovario & Correct & - \\
\hline Uterus & 6 & H3.07.01.3.00001 & Uterus & Útero & Correct & - \\
\hline Cell & 5 & H1.00.01.00001 & Cellula & Célula & Correct & - \\
\hline $\begin{array}{l}\text { Reproductive } \\
\text { system }\end{array}$ & 5 & H3.07.00.0.00001 & Systemata genitalia & $\begin{array}{c}\text { Sistema } \\
\text { genital }\end{array}$ & Incorrect & Synonymy \\
\hline Testicles & 2 & H3.07.02.1.00001 & Testis; Orchis & Testículo & Correct & - \\
\hline
\end{tabular}

Example of some terms used in 10th grade program (Unit 2).

Abbreviation: FIPAT, Federative International Programme for Anatomical Terminology; MINEDUC, Ministry of Education of Chile.

\section{RESULTS}

\section{Use of international terminology in high school curricula.}

Revision of the $9^{\text {th }}$ to $12^{\text {th }}$ grade programs reported that $88.57 \%$ of used terms are used under FIPAT considerations, while $11.43 \%$ of the terms correspond to linguistic variations which are not on the official list provided by FIPAT (Table II).

Regarding to terms that present linguistic variations, $93.75 \%$ correspond to synonyms, while $6.25 \%$ correspond to eponymies.

\section{Use of international terminology according to year and unit.}

Individual program analysis showed that $11^{\text {th }}$ grade reports the greatest number of morphological terms and has the greatest number of linguistic variations in units: Nervous system (18.18\%); Homeostasis and internal regulation (20\%); Nervous Response $(4.54 \%)$, (Table II). On the other hand, units that did not show linguistic variations correspond to Evolution (Unit 4, eleventh grade) and Expression and manipulation of genetic material (Unit 1, 12 ${ }^{\text {th }}$ grade) (Table III).

Table II. Use of international anatomical terminology in study curriculum from $9^{\text {th }}$ to $12^{\text {th }}$ grade (MINEDUC).

\begin{tabular}{ccc}
\hline & Total of terms in secondary educational level & $\%$ \\
\hline Terms used according to FIPAT & 124 & 88,57 \\
Terms not used according to FIPAT & 16 & 11,43 \\
Total of used terms & 140 & 100 \\
\hline
\end{tabular}

Abbreviation: FIPAT, Federative International Programme for Anatomical Terminology; MINEDUC, Ministry of Education of Chile. 
Table III. Use of international anatomical terminology by unit in study curriculum from $9^{\text {th }}$ to $12^{\text {th }}$ grade (MINEDUC).

\begin{tabular}{|c|c|c|c|c|c|c|c|}
\hline LEVEL & UNIT & $\begin{array}{l}\text { Total of used terms } \\
\text { in IAT/IET/IHT }\end{array}$ & $\begin{array}{l}\text { Correct } \\
\text { terms }\end{array}$ & $\begin{array}{l}\text { Incorrect } \\
\text { terms }\end{array}$ & Synonymy & Eponymy & $\begin{array}{l}\% \text { of } \\
\text { incorrect } \\
\text { terms }\end{array}$ \\
\hline 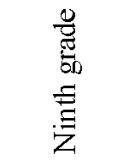 & $\begin{array}{l}\text { Unit 1: Structure and } \\
\text { function of living } \\
\text { beings: Structure and } \\
\text { function of the cell }\end{array}$ & 27 & 24 & 3 & 3 & - & 11.11 \\
\hline \multirow{2}{*}{ 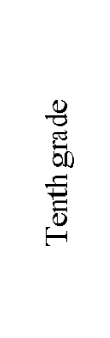 } & $\begin{array}{l}\text { Unit 1: Structure and } \\
\text { function of living } \\
\text { beings: Genetic and } \\
\text { cell reproduction }\end{array}$ & 22 & 22 & - & - & - & 0 \\
\hline & $\begin{array}{l}\text { Unit 2: Structure and } \\
\text { function of living } \\
\text { beings: Hormones and } \\
\text { human reproduction }\end{array}$ & 25 & 24 & 1 & 1 & - & 4 \\
\hline \multirow{4}{*}{ 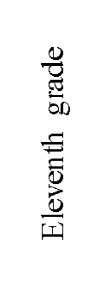 } & $\begin{array}{l}\text { Unit 1: Homeostasis } \\
\text { and internal regulation }\end{array}$ & 15 & 12 & 3 & 3 & - & 20 \\
\hline & $\begin{array}{l}\text { Unit 2: Nervous } \\
\text { system }\end{array}$ & 22 & 18 & 4 & 3 & 1 & 18.18 \\
\hline & $\begin{array}{l}\text { Unit 3: Nervous } \\
\text { response }\end{array}$ & 44 & 42 & 2 & - & - & 4.54 \\
\hline & Unit 4: Evolution & 3 & 3 & - & - & - & 0 \\
\hline \multirow{3}{*}{ 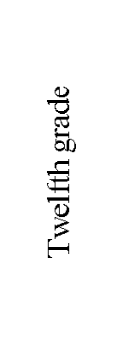 } & $\begin{array}{l}\text { Unit 1: Expression and } \\
\text { manipulation of } \\
\text { genetic material }\end{array}$ & 8 & 8 & - & - & - & 0 \\
\hline & $\begin{array}{l}\text { Unit 2: Immune } \\
\text { system: Structure and } \\
\text { function }\end{array}$ & 17 & 14 & 3 & 3 & - & 17.65 \\
\hline & $\begin{array}{l}\text { Unit 3: Immune } \\
\text { system: Illnesses and } \\
\text { treatments }\end{array}$ & 4 & 1 & 3 & 3 & - & 75 \\
\hline
\end{tabular}

Abbreviations: IAT: International anatomy terminology; IET: International embryologic terminology; IHT: International histologic terminology; MINEDUC, Ministry of Education of Chile.

Finally, units which did not present morphological terms corresponded to (i) Organisms, environment and their interactions: Matter and energy flows in the ecosystem (Unit 2, 9th grade); (ii) Organisms, environment and their interactions: Dynamics of populations and biological communities (Unit 3, 10 ${ }^{\text {th }}$ grade); (iii) Environmental issues (Unit $4,12^{\text {th }}$ grade).

\section{DISCUSSION}

\section{International morphology terminology in high school education.}

Analysis on international terminology used in high school curricula report that not all terms are used under the international terminology standards established by FIPAT $(11.43 \%)$. The greatest number of errors is concentrated in eleventh and twelfth grade units. Results discordant to those reported by Park \& Park (2005), who after analyzing 7 high school biology textbooks and purchasing them with the IAT, determined that concordance of high school biology terms with the IAT was $50.3 \pm 2.7 \%$, whereas with official biological terminology it was significantly higher $(89.8+/-1.6 \%)$. The most remarkable differences were found among terms that describe reproductive system. The units reporting the greatest number of errors are those referring to knowledge and comprehension of organism structures and system functions. It is expected that textbook revisions referring to these units may contain a greater number of errors in terminology, given 
the presence of a greater number of structures and terms used. Therefore, future research should be oriented to the analysis of school texts or teacher and/or student support texts.

The highest percentages of reported errors in the curricula refer to synonyms $(93.75 \%)$. This is due to several existing names to designate the same structure. Synonyms seem to not be only a present problem in curricula because even in the same international terminology of the FIPAT, there are up to 3 terms to designate a single structure. This is the case of Myelencephalon (A14.1.03.003), a term that in the eleventh grade program appears under the name of Bulb, the third of 3 possible alternatives to the same structure present in the official listing of the FIPAT (possible terms are in order): Myelencephalon, medulla oblongata and bulb.

In addition, there are other terms being used that are not present on the official list of IAT, like the terms used in eleventh grade. These terms correspond to: Dendrite, myelin sheath, sympathetic and parasympathetic division of the nervous system, among others. In view of this situation, it is suggested to do the appropriated incorporations of this terms in Latin language with their correct translation in the corresponding languages corresponding incorporations are suggested of these terms in Latin with their correct translation in the corresponding languages. Error also found by Park \& Park, who observed the presence of unofficial terms besides several eponymous in high school biology textbooks.

These errors were also identified by Kachlik et al. (2015), who classify them into seven groups: IAT errors, IAT discrepancies, word multiplication, IAT synonyms, identical terms for different structures, terms too long, and terms missing in the IAT. The latter group includes missing terms in systemic anatomy and clinical anatomy, and a scarcity of terms in variant anatomy, locomotion systems, and topographic anatomy.

In relation to results obtained in the context of teaching and learning environments, recent research shows that student knowledge of anatomy is not obtained for IAT purposes, because there is a wider knowledge of basic anatomical medical concepts using eponyms, a situation caused because the use of IAT is not reinforced during different stages of the student (Parra Gámez et al., 2015) and because teachers use anatomical terms which are inconsistent with FICAT recommendations (Martin et al., 2009). In addition, data demonstrate that clinical anatomists are not consistent in how they use IAT (Martin et al., 2014). This lack of international terminology in teaching is accompanied by curricular proposals (such as the high school curriculum in biology) with errors in the terminology. This is consistent with the fact that there are a large number of published anatomy textbooks which have not been carefully reviewed by experienced anatomists (Manzanares-Céspedes, 2010).

\section{Proposals for improving terminology use in school education processes.}

Some authors propose that the improvement in the use of IAT, goes through a series of changes in part by specialists, official list modifications and diffusion of international terminology in morphology (Pawlina \& Drake, 2009). Improving accessibility to a complete document including the latest version of terminology is recommended in the different areas of morphology (Martin et al., 2009; Manzanares-Céspedes), as well as creating greater awareness in professionals directly linked to the morphology (Martin et al., 2009; Burdan et al.). Along the same lines, there are concrete proposals pointing to more rigorous reviews by journals (Pawlina \& Drake), as well as more rigorous writing and/or translation of scientific textbooks because most anatomy teachers, students (university students) and trainees (in the area of morphology) use them (Manzanares-Céspedes). Proposals are pertinent, but in light of research results, they are concentrated on the academy, reducing the impact on the curriculum and teacher and student training in biology and natural sciences.

From the above, we propose 5 focal points which are directly linked to school education and in favor of a correct use of basic international terminology in the area of morphology (Fig. 1). (i) Use of international terminology in school education: Students tend to use the same vocabulary as their teachers (Manzanares-Céspedes), so the correct use of terminology can positively affect students' scientific vocabulary management in morphology. (ii) Professional training of Biology and Natural Sciences teachers under international terminology terms: Implementation of updated terminology requires initial or ongoing training of teachers in which they can incorporate the international terminology guidelines in morphology and other biological sciences disciplines. At present there are almost no initiatives for making changes in educational programs that do not include the training and updating of teachers at a given time, so a strategy for change must necessarily include teacher professional training processes (Vezub, 2007). (iii) Curricular proposals consistent with international terminology use: Educational institutions (MINEDUC, 2018) consider that the use of correct terminology is important (MINEDUC), however it is imperative that curricular proposals incorporate updated terms in their curricular programming. (iv) Supplementary materials using international terminology: It is necessary that guides, tests and textbooks be designed using correct terminology to avoid confusion in students and teachers regarding correct names of structures as well as their correct use. (v) Research focused on the use of international terminology in teaching and learning biology: It is important that new research show how natural science and biology teachers manage basic morphology concepts present in the curriculum. It is also 


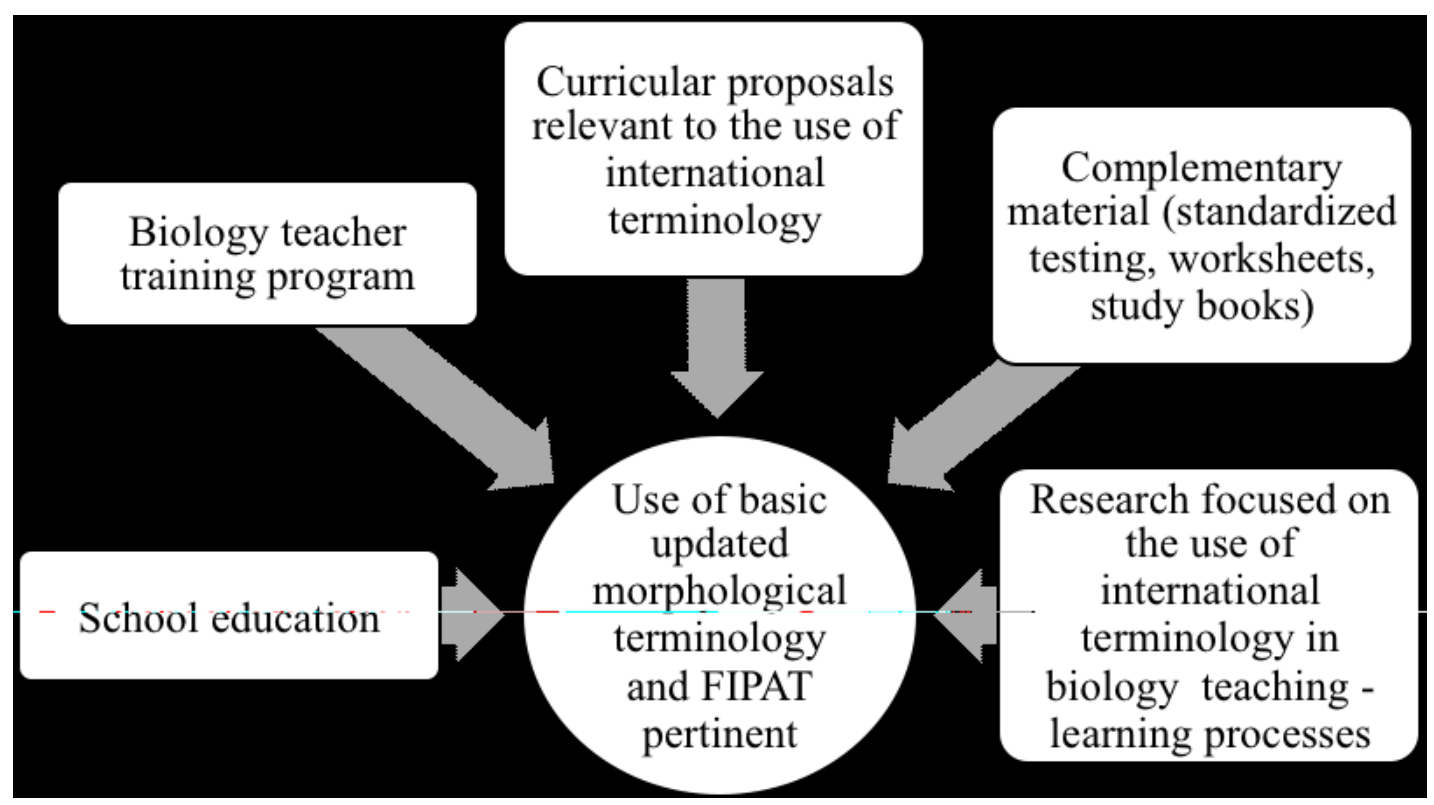

Fig. 1. Curricular proposals to improve the use of terminology in the school education and professional training processes. Five axis are proposed in order to improve the use of basic international terminology on morphological teaching - learning and professional contexts.

important that both, complementary materials and future curricular modifications be studied consistently as to give feedback to corresponding entities about the correct use of international terminology in morphology.

\section{CONCLUSIONS}

These results can serve as valuable basic resources for the revision and standardization of terminology used in biomedical fields. Collaboration between anatomists, biologists and high school teachers is a requirement necessary to make changes in the curricula to improve the use of IAT in teacher training and in Biology and Natural sciences classes.

\section{ACKNOWLEDGEMENTS}

The authors are grateful to the Dirección de Investigación, Vice-rectoría de Investigación y Estudios Avanzados and the Instituto de Biología of the Facultad de Ciencias de la Pontificia Universidad Católica de Valparaíso, Chile, and second author (RI) to CONICYT-PCHA/Doctorado Nacional/2015-21150235 for their constant support.
The institutions had no role in data gathering, data analysis, or writing of the report.

CARO, G.; ROA, I.; HORMAZÁBAL PERALTA, A.; LIZANA, P.A. Uso de la Terminología Anatómica Internacional en el Currículo Nacional de Biología en Enseñanza Media. Int.J. Morphol.,36(3):785$791,2018$.

RESUMEN: En Chile, el currículo nacional de ciencias (biología) es estandarizado y diseñado por el Ministerio de Educación (MINEDUC). Este estudio contribuye a la educación en ciencias analizando el currículo ministerial implementado y su adherencia al Federative International Programme for Anatomical Terminology (FIPAT). El objetivo de este estudio fue evaluar el uso de la Terminología Anatómica Internacional (TAI) en el programa nacional de educación en ciencias, implementado en Chile desde el 2009. Se realizó el análisis de los términos usados en el programa de educación secundaria del MINEDUC ( $9^{\text {no }}$ a $12^{\mathrm{mo}}$ año). Los términos se identificaron usando el software de análisis de texto Atlas.ti. Luego, se tabularon según: frecuencia, término en latín, traducción al español, uso de términos de acuerdo a FIPAT y tipo de error. Nuestros resultados muestran que el 11,43\% de la terminología usada en el currículo de enseñanza de la biología en secundaria no se adhiere a IAT según FIPAT. El $9^{\text {no }}$ grado de educación en biología muestra el mayor grado de uso de terminología FIPAT, no obstante, también muestra la mayor prevalencia de uso incorrecto de términos. Estos resultados sirven como una importante base para la revisión y estandarización de la terminología utilizada en el campo de la enseñanza de las ciencias. La colaboración entre anatomistas, biólogos y profesores es necesaria para ha- 
cer cambios en los currículos y mejorar el uso de IAT en la formación docente y en las clases de biología y ciencias naturales.

PALABRAS CLAVE: Terminología anatómica; Educación científica; Estudiantes secundarios; Enseñanza de la biología.

\section{REFERENCES}

Acuña, M.; Sinagra, A.; Pérez, M.; Macchia, E.; Manganiello, S. \& Conesa, H. A. Acerca de la Terminología Anatómica. Rev. Neurocir., 9(4):114-7, 2007.

Algieri, R. D.; Ferrante, M. S. \& Pró, E. Analysis of the general surgeon’s knowledge of International Anatomical Terminology (IAT). Int. J. Morphol., 31(4):1511-6, 2013.

Araujo, J. C.; García-Fontalvo, E. \& Sánchez, M. El origen histórico de los términos anatómicos. Una reflexión en torno a los epónimos, su pasado, presente y futuro. Botica, 47(4), 2015. Available from: http:/ /botica.com.ve/PDF/botica48.pdf

Burdan, F.; Dworzanski, W.; Cendrowska-Pinkosz, M.; Burdan, M. \& Dworzanska A. Anatomical eponyms - unloved names in medical terminology. Folia Morphol. (Warsz), 75(4):413-38, 2016.

Cruz, G. A.; Rodríguez, T. A.; Prates, J. C.; Losardo, J. R. \& Barbato, V. N. Ibero-Latin-American Symposia Terminology. Anatomy, Histology and Embryology. Int. J. Morphol., 28(1):333-6, 2010.

Díaz Rojo, J. A. La terminología médica: Diversidad, norma y uso. Panace, 2(4):40-8, 2001.

Evans, D. J. Connecting with different audiences: the anatomy of communication is essential. Anat. Sci. Educ., 6(2):134-7, 2013.

Federative International Programme for Anatomical Terminology (FIPAT). Programme for Anatomical Terminology of the International Federation of Associations of Anatomists (IFAA). Halifax, Dalhousie University Libraries, 2017. Available in: http:// fipat.library.dal.ca

Gómez, C.; Jiménez, H. \& Ulloa, J. H. Nomenclatura de las venas de los miembros inferiores y términos en flebología: los consensos internacionales. Rev. Colomb. Cir., 27(2):139-45, 2012.

Jiménez Gutiérrez, I. La sinonimia y la polisemia en la terminología anatómica: Términos de ubicación y de relación de estructura anatómicas. Entreculturas, (1):579-97, 2009.

Kachlik, D.; Baca, V.; Bozdechova, I.; Cech, P \& Musil, V. Anatomical terminology and nomenclature: past, present and highlights. Surg. Radiol. Anat., 30(6):459-66, 2008.

Kachlik, D.; Musil, V. \& Baca, V. Terminologia Anatomica after 17 years: inconsistencies, mistakes and new proposals. Ann. Anat., 201:8-16, 2015.

Losardo, R. J.; Cruz, G. A.; Rodríguez, T. A.; Prates, J. \& Barbato, N. E. V. B. Iberia-Latin-American Symposia of Morphological Terminology (SILAT). First two years and statute. Int J Morphol., 28(4): 1323-6, 2010.

Losardo, R. J.; Prates, N. E. V. B.; Arteaga-Martínez, M.; Cabral, R. H. \& García-Peláez, M. I. International Morphological Terminology: More than Anatomy, Histology and Embryology. Int. J. Morphol., 33(1):400-7, 2015.

Manzanares-Céspedes, M. C. On-line Terminologia Anatomica: a proposal. Anat. Sci. Educ., 3(3):154-5, 2010.

Martin, B. D.; Thorpe, D.; Barnes, R.; Deleon, M. \& Hill, D. Frequency in usage of FCAT-approved anatomical terms by North American anatomists. Anat. Sci. Educ., 2(3):94-106, 2009.

Martin, B. D.; Thorpe, D.; DeLuna, V.; Howard, T.; Hagemeyer, J. \& Wilkins, N. Frequency in usage of Terminologia Anatomica terms by clinical anatomists. J. Biomed. Educ., 2014: 950898, 2014.
Ministry of Education (MINEDUC). Orientaciones Preliminares para la elaboración de textos escolares ciencias naturales. Santiago de Chile, Ministry of Education, Government of Chile, 2016. Available from: http://www.textosescolares.cl/usuarios/tescolares/File/ Orientaciones_Ciencias\%20Naturales\%20_TE_GDD.pdf

Ministry of Education of Chile (MINEDUC). Curriculum nacional. Santiago de Chile, Ministry of Education, Government of Chile, 2018. Available from: http://www.curriculumenlineamineduc.cl/605/w3propertyvalue-49397.html

Park, K. H. \& Park, J. Study on the differences between anatomical terminology and terminology of high school biology textbook. Korean J. Anat., 38(4):307-14, 2005.

Parra Gámez, L.; Ibarra Ramírez, V. H.; González Ríos, J. \& García Hidalgo, A. A. El reconocimiento de conceptos básico-clínicos bajo la terminología anatómica internacional hacia la formación médica. Investig. Educ. Med., 4(15):139-44, 2015.

Pawlina, W. \& Drake, R. Moving forward with Terminologia Anatomica. Anat.Sci.Educ., 2(3):93, 2009.

Salgado, A. G. E. \& Trujillo, H. E. G. Terminología: Historia e importancia en el desarrollo de las ciencias morfológicas. Forensic Oral Pathol.J., 1(1):9-11, 2010.

Strzelec, B.; Chmielewski, P. P. \& Gworys, B. The Terminologia Anatomica matters: examples from didactic, scientific, and clinical practice. Folia Morphol.(Warsz), 76(3):340-7, 2017.

Vezub, L. F. La formación y el desarrollo profesional docente frente a los nuevos desafíos de la escolaridad. Profr. Rev. Curric. Form. Profr., 11(1):1-22, 2007. Available from: https://recyt.fecyt.es/index.php/profesorado/article/view/41838/23864.

Whitmore, I. Terminologia anatomica: new terminology for the new anatomist. Anat.Rec., 257(2):50-3, 1999.

\section{Corresponding author:}

Dr. Pablo A. Lizana

Laboratory of Morphological Sciences

Instituto de Biología

Pontificia Universidad Católica de Valparaíso

Avda. Universidad 330

Valparaíso

CHILE

\section{E-mail: pablo.lizana@pucv.cl}

Received: 16-03-2018

Accepted: $31-05-2018$ 